\title{
Service quality and customer satisfaction in the hotel industry in Serbia
}

\author{
Milan Vujić ${ }^{1}$, Snežana Đorđević ${ }^{2}$, Marija Lakićević ${ }^{3 *}$ \\ ${ }^{1}$ College of Vocational Studies in Aranđelovac, Serbia \\ ${ }^{2} \mathrm{PhD}$ student, University of Kragujevac, Faculty of Hotel Management and Tourism in \\ Vrnjačka Banja, Serbia \\ ${ }^{3}$ University of Kragujevac, Faculty of Hotel Management and Tourism in Vrnjačka Banja, \\ Serbia
}

\begin{abstract}
The significance of quality measurement and the value of components of a hotel service offer can be observed in the connection with the clients' satisfaction. The goal of this paper is to measure the level of satisfaction with the quality of hotel service, i.e. to identify the possibilities for establishing and development of long-term relations with the hotel's clients. Happy guests show a larger degree of satisfaction and loyalty and they visit the hotel again, recommend it to their friends, which affects the hotel's profits, and the development of tourism as a whole. The research was conducted in eight hotels in Serbia. Primary data were obtained by using survey method and 87 respondents, all of which were the guests of the hotels. The respondents expressed their claims on 7 points of Likert scale. The data analysis was conducted by applying the statistical program IBM SPSS (Statistical Package for the Social Sciences SPSS 20).
\end{abstract}

Keywords: service quality, consumer satisfaction, tourism, hotel management

JEL classification: M21, Z30

\section{Kvalitet usluga i zadovoljstvo korisnika u hotelijerstvu Srbije}

Sažetak: Značaj merenja kvaliteta i vrednosti komponenti uslužne ponude hotela ogledaju se u njihovoj povezanosti sa satisfakcijom gostiju. Cilj rada jeste prikazivanje nivoa zadovoljstva kvalitetom hotelskih usluga, odnosno sagledati mogućnosti za uspostavljanje i razvijanje dugoročnih odnosa sa gostima hotela. Zadovoljni gosti ispoljavaju veći stepen satisfakcije i lojalnosti, pa će ponovo posetiti hotel, preporučiti ga prijateljima što utiče na profit hotela, a time i na razvoj turizma u celini. Istraživanje je sprovedeno u osam hotela u Srbiji. Primarni podaci prikupljeni su metodom anketiranja, pri čemu je anketirano 87 ispitanika koji su bili gosti hotela. Ispitanici su svoje statove iskazivali na sedmostepenim Likertovim skalama. Analiza podataka je sprovedena primenom statističkog programa IBM SPSS (Statistical Package for the Social Sciences SPSS 20).

Ključne reči: kvalitet usluga, satisfakcija potrošača, turizam, hotelijerstvo JEL klasifikacija: M21, Z30

․ㅡarija.lakicevic@kg.ac.rs 


\section{Introduction}

The hotel industry today represents a global industry, which consists of global consumers who use hotel services all around the world. The use of hotel facilities such as: room, restaurant, bar, fitness center, and pool are no longer considered a luxury. For many hotel customers, these facilities are the constituent component of the hotel (Sekulić \& Mandarić, 2013). A thorough strategy of hotel companies starts with the idea that the value components of the hotel's offer package should reflect a high level of quality services provided. This concept is a base for many domestic, and especially international theoretical and empirical studies, which accept the fact that a high level of value components of hotels' offer package has positive implications on customers' satisfaction, and to the business performance of hotel companies and their competitive advantage. The customers satisfaction in terms of hotel management represents a sum of overall satisfaction with different services offered in the hotel. Different factors can impact customers' satisfaction. Accordingly, the quality is actually one of the satisfaction catalysts, and often the main one (Marinković \& Sekulić, 2016).

Quality is most often defined as a sum of characteristics of products or services with the capacity to meet explicit and implicit needs (Kotler et al., 2010). The research subject of this paper is the satisfaction of customers, the users of the hotel service offered. Based on that, the value components of the hotel's service offered and the customers satisfaction represent the key factor of long-term profitability and hotel management development contribution to the overall tourism development.

\section{Review of literature}

\subsection{Tourism multiplier effect as exemplified by hotel companies service quality}

The role of service quality in the success of hotel companies is essential. Hotel managers must have substantial understanding of what exactly the customers want (Akbaba, 2006). In order to achieve competitive advantage, hotel companies must search for a profitable way to differentiate on the market. One of the successful strategies is related to delivering high quality services in the environment of intense domestic and international competition (Rao \& Kelkar, 1997). The quality as a market concept means production and service offer that fully meets customers' needs, wishes, and expectations (Radosavljević, 2009). Parasuraman et al. (1985) observe the service quality from the customer's point of view, and compare their expectations with the perception of delivered service. The quality service represents one of the most important 'triggers' of customer's loyalty and generates wide scope of interests among researchers and practitioners (Marinković \& Senić, 2012).

Hotel service quality becomes the key determiner of business performance and its competitive advantage. Additionally, from the point of view of the tourist as the customer, and the hotel as the offer provider, the quality of hotel services becomes important determinant of tourism multiplicative development factor in Serbia. The benefits of hotel industry provide for the development of many other businesses i.e. successful business never stands alone. The increase of consumption of a tourism company (hotel) implies the increase of production in non-tourism sectors, such as food, drinks, equipment, etc., that is a side effect of a successful hotel industry. These stand for a multidimensional significance and integral characteristic of quality hotel services, as well as its dependence on customers' satisfaction and tourism resource multiplier. Many national economies see a chance for economic progress in hotel industry and tourism in general, as an industry branch with best prospects. While modern economic trends are related to a number of problems, and 
economies deal with unemployment and social changes on the one side and intensive work and stress on the other side, this, at the same time, enables the development of tourism industry which plays an important role in GDP and employment creation (Milovanović \& Milićević, 2014).

The money spent by foreign tourists does not stop circulating (Tiebout, 1960). Both hosts and guests engage in new consumption behaviors as a result of cross-cultural contact in the context of tourism and domestic economy with increase of incomes. That reflects the multiplicative effects of tourism and hotel industry on the economy of a country. According to Vizek (2008) "the multiplicative effects of tourism are based on the fact that the resources of tourist consumption after its basic circulation, continue to circulate in economy and affect all economy of the country, until the moment when, through imports, travels of the domestic population abroad, and retrieving the money from circulation in the form of savings, they 'flow out' again."

Tourists spend money on hotels and restaurants, transportation, tourist agencies, markets, sports events, cultural sites, etc. The multiplicative effects of tourism decrease if tourists are consumers of imported goods and services and not domestic. In that case, incomes from tourism is profitable, but it is disputable whether such income increases the domestic or foreign production. (Bošković, 2009). Tourism multiplier can be explained by the example of hotel companies which spend part of the earnings on non-tourist sectors, in order to provide food and drinks, and equipment, that is the source of income for the producers of these products. The hotel's consumption as a tourism company in non-tourism sectors is seen as an indirect impact on their development. The larger the number of transactions is, the larger the multiplier is, but under the condition that the money from tourists' consumption is not spent on imported goods. With the import components or savings increase, the tourist multiplier decreases, and vice-versa. The analysis of the structure of a tourist product is very difficult to determine, which also means it is very difficult to find out how much each business directly or indirectly participates in the tourist product (Milićević, 2016).

\subsection{Concept of customer satisfaction in hotel industry}

If we perceive the satisfaction from a conceptual view, we can observe it as a result or as a process $(\mathrm{Yi}, 1990)$. The customers' satisfaction as a result represents a state which is a consequence of an experience resulting from a purchased product or a used service. The satisfaction as a process represents a psychological process of evaluation. This process includes consumer's expectations and cause of pleasure sensed in servicing process.

In his researching of satisfaction, (Wong, 2004) sees satisfaction as a unity of cognitive and emotional reaction. Pleasure as cognitive concept means comparison of delivered product or service to expectations. On the other hand, pleasure as an emotional reaction appears through servicing process, in which customer's experience affects their feeling. Accordingly, the customer evaluates the product or the service based on their perception, but also on the feelings sensed in the process.

Other authors see the consumer's satisfaction as three mutually dependent and conditioning concepts. The first concept is related to the consumer's expectations from the product or the service. The second concept is related to meeting the customer's expectations. The third concept related to the customer's satisfaction compares the delivered value to the previous expectations. If the consumer's previous expectations are met, as a result there is a satisfied customer. On the contrary, when the previous expectations are not met, they result in customers' dissatisfaction (Javalgi, 2006).

Some authors believe that in service businesses, such as hotel management, the evaluation of 
service satisfaction is based on the evaluation of the satisfaction with individual service elements. Such evaluation offers detailed information, and the guests' satisfaction or dissatisfaction with individual service components affects the assessment of total satisfaction with provided services (Kozak \& Rimmington, 2000). In hotel management, the guests' satisfaction can be connected to different components of service such as the eye appeal and furnishing, attitude, courtesy and professionalism of the employees, additional contents, etc. The satisfaction with single components of the service affects total satisfaction of the guests (Grigoroudis \& Siskos, 2010). Based on the previous information, it can be said that there are different approaches to explaining satisfaction and dissatisfaction of customers. Thereby, Richard Oliver's theory of expectation and disconfirmation model of customer satisfaction is the most famous. According to the theory mentioned, the consumers purchase products and services in accordance with satisfaction experienced and delivery expectations (Oliver, 1980). There are numerous studies which indicate that hotel image and customer satisfaction with quality of housekeeping, reception, food and drinks, and price are positively correlated to their loyalty (Kandampully, 2010). In some businesses - such as travel, tourism, catering, and banking, the delivery of high quality services to customers is increasingly recognized as a key factor affecting the company performance. As expected service quality measurement has become the main subject of several empirical and conceptual studies in services marketing (Atilgan et al., 2003). Faced with intense market competition, it can be assumed that there is a limited number of customers prepared to deal with patronage. It is imperative for hotels to adapt hotel services to the changing needs and lifestyles of customers with a view of increasing customers' loyalty and retention (Min et al., 2002).

\section{Research desing}

Survey method is used for primary data collection. The questionnaire is conceived and structured so that it follows the cycle of hotel service customers (guests) from their arrival in the hotel to their departure. The goal of the survey is to measure the level of satisfaction with the hotel service offer package quality component the guest resides in. The questionnaire contains questions for the respondents in the form of claims and contains four parts:

- First part is related to claims that reflect the guests' satisfaction during their stay in the hotel.

- Second part includes questions related to general opinion over the stay in the hotel.

- Third part are questions about the hotel's brand name, as well as willingness for recommendation and the continuation of using hotel services.

- Fourth part of the questionnaire is related to general information about the respondents (sex, age, education, and motives for their stay in the hotel).

The respondents expressed their claims on 7 points of Likert scale. The stated claims were graded on the scale from 1 to 7 , where 1 denotes "absolute dissatisfaction", while 7 means "absolute satisfaction". The survey research was conducted in eight hotels in Serbia, during December, 2018, and first half of January, 2019, with 87 respondents, hotel guests who were surveyed. The data analysis was conducted by applying the statistical program IBM SPSS (Statistical Package for the Social Sciences SPSS 20). With reliability analysis, the Cronbach's alpha coefficient was determined for each individual value component, which shows whether the claims which were used to measure the subject variables are internally consistent. The multicollinearity problem with multiple regression analysis was examined on the basis of VIF value - Variance Inflation Factor (Hair et al., 2014).

The hotels in which the research was conducted are: "Kragujevac" in Kragujevac, "Park" in Belgrade, "Grand" in Valjevo, "Izvor" in Aranđelovac, "Omorika" on Mountain Tara, "Divčibare" on Mt. Divčibare, "Breza" in Vrnjačka Banja, "Vrujci" in Vrujici Spa. The graph 
chard of the number of the respondents to the survey in these hotels is shown below (Figure 1).

Figure 1: The number of questioned respondents by hotels

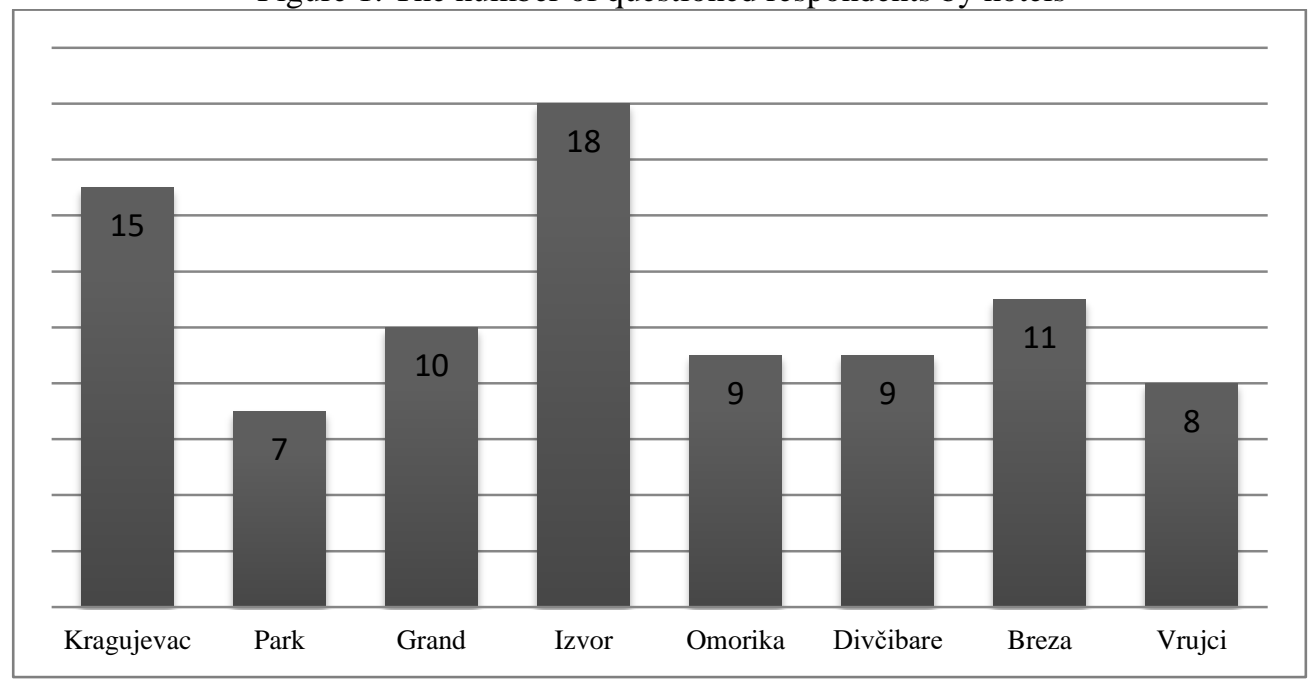

Source: Authors

Based on general questions in the questionnaire, the respondents are differentiated according to their sex, age, education and the motive of the stay at the hotel. Figure 2 shows the pie chart of the respondents differentiated by sex. As it can be noted according to the respondents' sex structure, out of the total number of respondents the largest relative share are males $53.0 \%$, while females follow with $47.0 \%$

Figure 2: Sample structure by sex

Figure 3: Sample structure by age
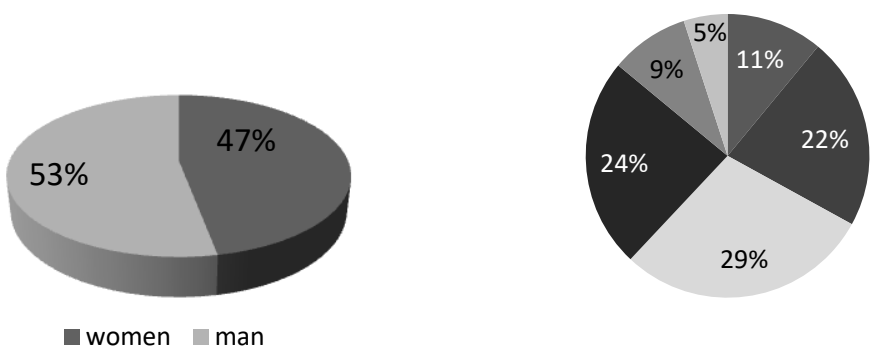

$$
\begin{gathered}
\text { below } 25 \\
25-34 \\
35-44 \\
-45-54 \\
55-64 \\
- \text { over } 65
\end{gathered}
$$

Source: Authors

Figure 3 illustrates the respondents differentiated by age. By observing the subsample structure of hotel guests, the largest number of respondents is of age between 35 and 44 $(29.0 \%)$. The smallest is the share of persons over $65(9.0 \%)$, while approximately an equal share goes to people age 25-34 (22.0\%) and 45-54 (24.0\%).

According to the subsample structure by education, the largest number of respondents has university degree (34.0\%), while a slightly smaller number of respondents has an associate' s degree in education (31.0\%), and $27.0 \%$ has high school education. By observing the sample structure of the motive of guests' stay in the hotel, the largest portion of respondents said that it is for the purposes of vacation (48.0\%), and $19.0 \%$ that the purpose is business. Likewise, $12.0 \%$ of respondents said that the motive for their stay are seminars, and $8.0 \%$ participation in conferences. $13.0 \%$ of respondents gave other reasons for their stay in the hotel. 
When a specific variable is measured in several claims, it is very important to calculate whether the given variable is reliable, i.e. whether the claims measured are internally consistent. For the purposes of this analysis, a value of Cronbach's alpha coefficient is calculated and measured between the intervals of 0 and 1. The claims are internally consistent, i.e. the variable is reliable if the value of this coefficient is 0.7 or more.

Table 1: Results of reliability analysis and descriptive analysis for formed variables

\begin{tabular}{|c|c|c|c|}
\hline Variable & Arithmetic mean & Standard deviation & Cronbach's alpha \\
\hline Hotel & 5.8953 & 0.88623 & 0.781 \\
\hline Staff & 6.1376 & 0.90220 & 0.935 \\
\hline Reception & 6.0773 & 0.87479 & 0.875 \\
\hline Room & 5.9640 & 0.89747 & 0.947 \\
\hline $\begin{array}{c}\text { The restaurant and the } \\
\text { bar }\end{array}$ & 6.0075 & 0.92372 & 0.914 \\
\hline Hotel's contents & 5.4560 & 1.38811 & 0.824 \\
\hline Price & 5.6574 & 1.12009 & 0.864 \\
\hline Renown & 5.9311 & 1.05939 & 0.895 \\
\hline Satisfaction & 5.8321 & 1.00453 & 0.878 \\
\hline Loyalty & 5.7033 & 1.24433 & 0.923 \\
\hline
\end{tabular}

Source: Authors

The formed variables represent the value components which the hotels offer to their guests. The claims related to amiability, complaisance, and neatness of the staff are grouped into the variable Staff. The general appearance of the hotel, the quality of the Internet connection in the hotel, the hotel's location and the cleanliness of the hotel together make for the variable Hotel. All claims related to check-in/check-out of the guests (accuracy of the reservation, availability of the room, check-in and check-out speed) make for the variable Reception. The appearance, equipment, cleanliness of the room and the bathroom together make for the variable Room. The claims for the food and drink quality in the restaurant, appearance and cleanliness of the restaurant and the bar make for the variable The restaurant and the Bar. Additional contents of the hotel (SPA centres, halls, parking spots, playgrounds, etc.) for the variable Hotel's contents. Claims which are related to the guests' satisfaction with the price, as well as the comparison of the price to other competitors make for the variable Price. The opinions of the hotel's brand name, recognition, and renown are grouped into the variable Renown. And finally, satisfaction with the hotel's services and offer make for the variable Satisfaction, while readiness for recommendation and the continuation of using the hotel's services is Loyalty.

\section{Research results}

Based on the descriptive analysis for the formed variables, it can be noted that the satisfaction of the guests of the hotel is highest with the Staff (arithmetic mean is the highest 6.14), Reception's work (6.08) and restaurant and bar's work (6.00). On the other hand, the guests are the least satisfied with the available Extra Services of the hotel (playgrounds, parking spots, SPA, etc.), for which the arithmetic mean is the lowest (5.46).

The most homogenous claims of the respondents are with the variable Reception, since the value of the standard deviation is the lowest. Variables Hotel and Room follow. On the other hand, the most heterogeneous claims of the respondents are with the diversity services of the hotel, for which the standard deviation is the highest. 
The regression analysis measures the influence of one independent variable on one dependent variable, and in that case it is the matter of a simple regression analysis. Aside from a simple one, there is a multiple regression analysis, where the influence of multiple independent variables on one dependent variable is measured. Beta coefficient $(\beta)$ shows the intensity of the influence of the independent variable on the dependent one. The higher value of the beta coefficient is, the stronger the influence is. If the sig value is larger than 0.05 , then the given independent variable does not have a statistically significant influence on the dependent variable. Also, in regression analysis, an indicator Determination coefficient $\left(\mathrm{R}^{2}\right)$ is used, which shows which percent of variability of the dependent variable is under the influence of the independent variable. The value of the determination coefficient is measured between intervals 0 and 1 . If it is higher than 0.4 it can be concluded that the regression model is good.

Table 2: Influence of independent variables on satisfaction - regression model 1

\begin{tabular}{|c|c|c|c|c|}
\hline Variables & sig. & $\mathbf{t}$ & $\boldsymbol{\beta}$ & vif \\
\hline Hotel & 0.000 & 5.522 & $0.256^{*}$ & 3.558 \\
\hline Staff & 0.000 & 6.494 & $0.267^{*}$ & 2.803 \\
\hline Reception & 0.000 & 3.182 & $0.128^{*}$ & 2.667 \\
\hline Room & 0.000 & 5.547 & $0.227^{*}$ & 2.768 \\
\hline
\end{tabular}

Source: Authors

* Value is significant at level 0.01 ;

$\mathrm{R}^{2}=0.702 * ; \mathrm{F}=248.931$

Given that the multiple regression consists of several independent variables, if they mutually influence each other, the problem of multicollinearity would appear, and in that case the beta values which show the influence of independent variables on a dependent variable would not be realistic, and the regression would not provide reliable results. In order to perceive the problem of multicollinearity, it is necessary that the value of variance inflation factor (vif) is lower than 10. The value $t$ corresponds with the beta coefficient, and if $t$ value is higher, beta coefficient is higher too. The results of the conducted multiple regression satisfaction analysis is presented in Tables 2 and 3.

Table 3: Influence of independent variables on satisfaction - regression model 2

\begin{tabular}{|c|c|c|c|c|}
\hline Variables & sig. & $\mathbf{t}$ & $\boldsymbol{\beta}$ & vif \\
\hline Restaurant and bar & 0.000 & 6.632 & $0.186^{*}$ & 2.579 \\
\hline Hotel contents & 0.000 & 4.265 & $0.101^{*}$ & 1.861 \\
\hline Price & 0.000 & 17.210 & $0.384^{*}$ & 2.607 \\
\hline Renown & 0.000 & 8.576 & $0.238^{*}$ & 2.532 \\
\hline
\end{tabular}

Source: Autors

* Value is significant on level 0.01 ;

$\mathrm{R}^{2}=0.751 * ; \mathrm{F}=659.416$

Considering that the inclusion of a large number of variables in a multiple regression model can lead to less accurate results, two regression models will be formed. The first model will measure the influence of the variables Hotel, Staff, Reception and room on the dependent Satisfaction variable. Second model will measure the influence of the variables the restaurant and the bar, service offer, price, and renown on satisfaction.

The data in the given regression model are suitable for analysis since the values of variance inflation factor (the last column) are less than 10. The determination coefficient is 0.702 , meaning that $70.2 \%$ of variability of satisfaction (dependent variable) is described with this 
model, accordingly this regression model is good. The value of determination coefficient is statistically significant on level 0.01 . All four variables have statistically significant influence on the guests' satisfaction (all values are lower than 0.05).

In the given regression model there is no problem of multicollinearity, meaning that all data is suitable for analysis (vif $<10$ ). The determination coefficient amounts to 0.751 , meaning that $75.1 \%$ of the dependent variable (satisfaction) is described with this regression model. Therefore, this regression model is applicable, too. The value of determination coefficient is statistically significant on level 0.01 . In the Regression model 2 all four variables have statistically significant influence on satisfaction.

When the influences of all eight processed variables in these two regression models are compared, there is a conclusion that the Price has the highest influence on the hotel guests 'satisfaction (since the $\beta$ coefficient is the highest and amounts to 0.384). The second strongest influence goes to the hotel's Staff. On the other hand, the least influence on the guests' satisfaction is related to other services of the hotel (SPA, playgrounds, parking spots, etc.). All variables have statistically significant influence on the guests' satisfaction.

\section{Conclusion}

The satisfaction of the customers with hotel service is the main prerequisite for their loyalty. The improvement of the guests' satisfaction and their retention leads to the increase of loyalty, which further leads to larger capacity usage and the increase of the hotel's profit per guest. A loyal customer contributes to the stability of business and the increase of hotel company incomes, which also contributes to the development of tourism. Based on the analysis of the variables, it is concluded that there is room for improvement in the level of services which would lead to the greater guests' satisfaction.

With the help of the previous two regression models it can be concluded that the value of hotels' offer components has a statistically significant influence on the guests' satisfaction. The regression models (Tables 2 and 3) imply that all eight analyzed variables have a statistically significant influence on the guests' satisfaction, with Price having the strongest one. Considering the sample size, the authors of this paper decided to use eight independent variables, which were divided into two models. The proposition for further research is to perform a single model and multiple regression. The presence of extreme data values should be reported with an established matrix of variable correlation coefficient.

\section{References}

1. Akbaba, A. (2006). Measuring service quality in the hotel industry: A study in a business hotel in Turkey, International Journal of Hospitality Management, 25(2), 17019. https://doi.org/10.1016/j.ijhm.2005.08.006

2. Atilgan, E., Akinci,S., \& Aksoy,S. (2003) Mapping service quality in the tourism industry, Managing Service Quality: An International Journal, 13(5), 412-422. https://doi.org/10.1108/09604520310495877

3. Bošković, T. (2009). Turizam kao factor privrednog razvoja [Tourism as a factor of economic development] Škola biznisa 27(3), 5-23. Retrieved May 2, 2019 from http://www.vps.ns.ac.rs/SB/2009/2.3.pdf

4. Grigoroudis, E., \& Siskos, Y. (2010). Customer Satisfaction Evaluation: Methods for Measuring \& Implementing Service Quality, Springer Science and Business Media, LLC (pp.12-13), New York.

5. Hair, F. J., Black, C. W., Babin, J. B. \& Anderson, E. R. (2014). Multivariate Data Analysis. Pearson Education Limited, Harlow. 
6. Javalgi, R., Martin, C., \& Young, R. (2006). Marketing Research, Market Orientation and Customer Relationship Management: A Framework and Implications for Services Providers, Journal of Services Marketing, 20(1), 12-23. https://doi.org/10.1108/08876040610646545

7. Kandampully, J. (2000). Customer loyalty in the hotel industry: the role of customer satisfaction and image, International Journal of Contemporary Hospitality Management, 12(6), 346-351. https://doi.org/10.1108/09596110010342559

8. Kotler, P., Bowen, J., \& Makens, J. (2010), Marketing u ugostiteljstvu, hotelijerstvu $i$ turizmu [Marketing in catering, hospitality and tourism], Mate Zagreb.

9. Kozak, M., \& Rimmington, M. (2000). Tourist Satisfaction with Mallorca, Spain, as an Off-SeasonHoliday Destination, Journal of Travel Research, 39(3), 260-269. https://doi.org/10.1177/004728750003800308

10. Marinković, V., \& Senić, V. (2012). Analiza elemenata kvaliteta usluga u korporativnom bankarstvu [The analysis of service quality elements in corporate banking], Ekonomski horizonti, 14(1), 13-22. doi:10.5937/ekonhor1201013M

11. Marinković,V., \& Sekulić, D. (2016). Motiv boravka kao kriterijum segmentacije korisnika hotelijerskih usluga [The motive of stay as a criterion in segmentation of users of hotel services], Menadžment $u$ hotelijerstvu i turizmu, 4(2), 25-35 Retrieved May 2, $2019 \quad$ from http://www.hitvb.kg.ac.rs/htmanagement/index.php/HITM/article/view/42/28

12. Milovanović, V., \& Milićević, S. (2014). Management of Serbian tourism products as a condition for improving its competitiveness on the international tourism market. Menadžment u hotelijerstvu i turizmu - Hotel and Tourism Management, 2(1), 38-48.

13. Milićević, R. (2016). Resursne atrakcije kao multiplikativni factor razvoja zdravstvenog turizma Srbije [Resource attractions as a multiplicative factor of development of sanitary tourism in Serbia], Ekonomski fakultet Univerziteta u Kragujevcu.

14. Min, H., Min, H., \& Chung, K. (2002). Dynamic benchmarking of hotel service quality, Journal of Services Marketing, 16(4) 302-321. https://doi.org/10.1108/08876040210433211

15. Oliver. R. L. (1980)A cognitive model of the antecedents and consequences of satisfaction decisions, Journal of Marketing Research, 17(4), 460-469. https://doi.org/10.1177/002224378001700405

16. Parasuraman, A., Zeithaml, V. A. \& Berry, L. L. (1985) A conceptual model of service quality and its implications for future research, Journal of Marketing, 49, 41-50. https://doi.org/10.1177/002224298504900403

17. Radosavljević, G. (2009). Menadžment u turizmu [Management in tourism], Kragujevac: Ekonomski fakultet.

18. Rao, C. P., \& Kelkar, M. M. (1997). Relative impact of performance and importance ratings on measurement of service quality, Journal of Professional Services Marketing, 15(2), 69-86. https://doi.org/10.1300/J090v15n02_06

19. Sekulić, D., \& Mandarić, M. (2013). Kvalitet usluga kao determinant satisfakcije potrošača u hotelijerstvu [Quality of Services as a Determinant of Customer Satisfaction in the Hotel Industry], Marketing, 44(3), 231-246. doi:10.5937/markt1303231S

20. Tiebout, C. M. (1960). Community Income Multipliers: A Population Growth Model. Journal of Regional Science, 2(1), 75-84. https://doi.org/10.1111/j.14679787.1960.tb00836.x

21. Vizek, M. (2008). Analiza odrednica hrvatskog turističkog sektora [Analysis of determinants of the Croatian tourist sector]. Privredna kretanja i ekonomska politika (pp. 58-81) Zagreb: Ekonomski fakultet. 
Vujić, M., et al. - Service quality and customer satisfaction in the hotel industry in Serbia-

Hotel and Tourism Management, 2019, Vol. 7, No. 1: 61-70.

22. Wong, A. (2004). The role of emotions in service encounters, Managing Service Quality, 14(5), 365-376.

23. Yi, Y. (1990). A critical review of consumer satisfaction, u Zeithaml, V. (Ed.) Review of Marketing (pp. 68-123). Chicago: American Marketing Association.

Received: 8 May 2019; Sent for revision: 11 May 2019; Accepted: 27 May 2019 